\title{
Ectopic pregnancy following levonorgestrel emergency contraception: a case report
}

\author{
Levonorgestrelli acil kontrasepsiyon sonrası ektopik gebelik: Olgu sunumu
}

\author{
Oktay Kaymak, Yavuz Şimşek, Melike Doğanay, Yasemin Yıldız, Leyla Mollamahmutoğlu \\ Dr. Zekai Tahir Burak Training and Research Hospital, Ankara, Turkey
}

\section{Abstract}

Hormonal contraceptive pills containing 750 microgram levonorgestrel are the most commonly used postcoital contraceptive method because of their high efficacy and fewer side effects. Emergency contraceptive pills containing levonorgestrel present their effects by several mechanisms, including delayed tubal transport of the ovum. A delay of tubal transportation of an ovum is also one of the possible etiologic factors of tubal ectopic pregnancies. There are limited data on the risk of ectopic pregnancy following levonorgestrel treatment as an emergency contraception. Here, a case of tubal pregnancy associated with the use of levonorgestrel containing emergency contraceptive pills has been presented along with discussion of the relevant literature. (J Turkish-German Gynecol Assoc 2010; 11: 168-9)

Key words: Emergency contraception, extrauterine pregnancy, levonorgestrel

Received: 17 November, 2009

Accepted: 3J anuary, 2010

\section{Introduction}

Either elective or criminal termination of unwanted pregnancies is still a major health problem in developing countries. Emergency contraception (EC) has been practiced in the last 3 decades in order to prevent unwanted pregnancies and to protect women against unsafe abortions $(1,2)$. Levonorgestrel (LNG) is a synthetic derivative of progestogen. Use of $750 \mu \mathrm{g}$ levonorgestrel containing emergency contraceptive pills (ECP) in 2 doses at 12-hour intervals as EC is a safe and effective measure for preventing an unwanted pregnancy. After long-term and widespread use, its efficacy and safety have been confirmed in two large series in the multiple clinical trial by World Health Organization (WHO) $(1,2)$. Possible mechanisms of action of LNG containing ECP are inhibition of ovulation, decreased tubal motility, and certain changes in the endometrial secretory pattern (3). Tubal mucosal damage secondary to either pelvic infections or previous surgery and tubal motility changes due to the use of hormonal contraceptive methods are the known causes of tubal ectopic pregnancy (4). Beyond the theoretical relationship between the LNG-ECP and ectopic pregnancy, several case reports of extrauterine pregnancies have been published

\section{Özet}

750 Mg levonorgestrel içeren hormonal kontraseptif haplar, yüksek etkinlikleri ve düşük yan etki profilleri ile en yaygın kullanılan kontraseptif yöntemlerdir. Levonorgestrelli acil kontraseptif haplar, ovumun tubal transportunun gecikmesini de içeren çeşitli mekanizmalarla gebelikten koruyucu etki gösterirler. Ovumun tubal transportunun gecikmesi aynı zamanda tubal ektopik gebelikler için de bir risk faktörüdür. Levonorgestrelli acil kontraseptif hap kullanımı sonrası ektopik gebelik riski ile ilgili sınırlı bilgiler mevcuttur. Bu yazıda acil kontrasepsiyon amacıyla levonorgestrelli hap kullanımı sonrası oluşan tubal ektopik gebelik olgusu sunulmuş ve konu ilgili literatür bilgileri eşliğinde tartşılmıştr. (J Turkish-German Gynecol Assoc 2010; 11: 168-9)

Anahtar kelimeler: Acil kontrasepsiyon, ekstrauterin gebelik, levonorgestrel

Geliş Tarihi: 17 Kasım 2009

Kabul Tarihi: 03 Ocak 2010

after using LNG as EC (5). Here, we present a patient with ectopic pregnancy after using LNG for EC.

\section{Case Report}

The patient was a 24-year-old unmarried female, gravida 1, parity 0 , and a normal menstrual period of 28 days. After a single unprotected intercourse in her follicular phase (day 11), she had taken $750 \mu \mathrm{g}$ levonorgesterol $\left(\right.$ Norlevo $^{\mathrm{TM}}$ ) 16 hours and 28 hours later. Three weeks later, on the $15^{\text {th }}$ of May, 2009, she was first seen in our hospital. Her complaints were lower abdominal pain and light vaginal bleeding. The patient's level of serum $\beta$-human chorionic gonadotropin ( $\beta$-hCG ) was 2980 $\mathrm{mIU} / \mathrm{ml}$. Transvaginal ultrasound showed a complex structure of $3 \times 3 \times 4.3 \mathrm{~cm}$ in diameter in her left tube, with no evidence of intrauterine pregnancy. A diagnosis of ectopic pregnancy was made. the patient was given the necessary information and written informed consent of the patient was obtained. Since the patient had a history of chronic duodenal peptic ulcer, we excluded methotrexate as a treatment option for our patient. At laparoscopy, there was an unruptured ectopic pregnancy in the ampullar region of the left Fallopian tube, and laparoscopic left salpingostomy was performed. In addi- 
tion, endometrial sampling was performed. Histology of the endometrial sample confirmed arias-stella reaction. Tubal ectopic pregnancy was proven by the presence of chorionic villi in the left tubal tissue.

\section{Discussion}

Unwanted pregnancy can cause many social problems. In countries where safe abortion is not available, termination of pregnancy may lead to serious medical complications and maternal mortality. EC methods are safe and effective for preventing unwanted pregnancies. Yuzpe regimen and only LNG containing pills are the most commonly used contraceptive methods for EC worldwide. In the latter, $750 \mu \mathrm{g}$ LNG should be taken in 2 doses at 12-hour intervals within 72 hours after unprotected intercourse. However, it is now recommended to take $1,5 \mathrm{mg}$ in one dose instead of two $750 \mu \mathrm{g}$ doses (6). The use of levonorgestrel for EC was first reported by Ho and Kwan, as an alternative method to the Yuzpe regimen with its fewer side effects such as nausea and vomiting (7).

In the multicenter study of the World Health Organization (WHO), LNG-ECP was found to be more successful than the Yuzpe regimen (failure risks $1.1 \%$ and 3.2\%, respectively) (2). In their clinical study in 2003, Trussell et al reported a pregnancy rate of $5.2 \%$ after use of LNG-ECP (8).

The exact mechanism of action of LNG as a postcoital contraceptive is unknown. It is thought to work mainly by interruption of follicular development, inhibition of ovulation due to suppression of gonadotropins in the preovulatory period; and prevention of fertilization via decreased tubal motility and inhibition of implantation in the post-ovulatory period (3). Altering the capacity of sperms and making cervical mucus of a consistency to prevent sperm motility into the cervical canal are also common effects of LNG-ECP (1-3). The most effective period of LNG for EC has been reported to be in the preovulatory follicular phase $(3,5)$. Use of LNG-ECP after the ovulatory period and an increased interval between the unprotected intercourse and beginning of treatment have been described as main causes of failure (5). The patient presented here had used the treatment in the follicular phase as suggested previously as the most efficient period of the method. It is well known that a high level of progesterone causes a decrease in tubal motility and ciliary functions, when the risk of tubal ectopic pregnancy increased (3-5). Impaired tubal peristalsis may contribute to a delayed arrival of the egg in the endometrial cavity and implantation of the fertilized ovum in the tubes. There are few but increasing data regarding the possibility of an extrauterine pregnancy, in case of failure of LNG-ECP. Pereira et al reported two cases of ectopic pregnancies after the use of levonorgestrel close to the ovulatory period, and warned that attention should be paid to the risk of tubal pregnancy in case of failure of EC (5). Farkas et al reported a much higher risk (6.4\%) of ectopic pregnancy in users of levonorgestrel (9). Similarly, ShefferMimouni et al reported three cases of ectopic pregnancies after levonorgestrel use close to the ovulatory period (10).

Although the data on the relationship of ectopic pregnancy and LNG-ECP are limited, patients who have used LNG after unprotected intercourse and have a positive pregnancy test should be monitored closely in order to rule out a possible ectopic pregnancy.

\section{Conflict of interest}

No conflict of interest is declared by authors.

\section{R eferences}

1. von Hertzen H, Piaggio G, Ding J, Chen J, Song S, Bártfai G, et al. Low dose mifepristone and two regimens of levonorgestrel for emergency contraception: a WHO multicentre randomised trial. Lancet. 2002; 360: 1803-10.

2. Randomised controlled trial of levonorgestrel versus the Yuzpe regimen of combined oral contraceptives for emergency contraception. Task Force on Postovulatory Methods of Fertility Regulation. Lancet. 1998; 352: 428-33.

3. Marions L, Hultenby K, Lindell I, Sun X, St3bi B, Gemzell Danielsson $\mathrm{K}$. Emergency contraception with mifepristone and levonorgestrel: mechanism of action. Obstet Gynecol 2002; 100: 65- 71.

4. Cunningham FG, Gant NF, Leveno KJ, Gilstrap LC, Hauth JC, Wenstrom KD. Ectopic Pregnancy. In: Williams Obstetrics. 21st edition. McGraw-Hill; 2001. p. 883.

5. Pereira PP, Cabar FB, Raiza LCP, Roncaglia MT, Zugaib M. Emergency contraception and ectopic pregnancy: Report of 2 Cases. Clinics 2005; 60: 497-500.

6. Bastinelli C, Farris M, Benagiano G. Emergency contraception : A review. Eyr J Contracept Reprod Health Care 2008 ; 13 : 9-16.

7. Ho PC, Kwan MSW. A prospective randomized comparison of levonorgestrel with the Yuzpe regimen in post-coital contraception. Hum Reprod 1993; 8: 389-92.

8. Trussell J, Ellertson C, von Hertzen $\mathrm{H}$. Estimating the effectiveness of emergency contraceptive pills. Contraception. 2003; 67: 259-65.

9. Farkas M. The effect of oral ovulation inhibiting (mono-, bi- and triphase) contraceptives and of Continuin and Postinor on proteoand steroid hormones. Acta Pharm Hung. 1992; 62: 17-30.

10. Sheffer-Mimouni G, Pauzner D, Maslovitch S, Lessing JB, Gamzu R. Ectopic pregnancies following emergency levonorgestrel contraception. Contraception. 2003; 67: 267-9. 